\title{
AMYLOIDOSIS PRESENTING AS PERIPHERAL NEUROPATHY
}

\author{
Shilpa Dharmaraj ${ }^{1}$, R. Penchalaiah Ratakonda ${ }^{2}$
}

${ }^{1}$ Assistant Professor, Department of General Medicine, Kilpauk Medical College, Chennai, Tamilnadu.

2Professor, Institute of Internal Medicine, Madras Medical College, Chennai, Tamilnadu.

HOW TO CITE THIS ARTICLE: Dharmaraj S, Ratakonda RP. Amyloidosis presenting as peripheral neuropathy. J. Evolution Med. Dent. Sci. 2018;7(21):2646-2648, DOI: 10.14260/jemds/2018/594

\section{PRESENTATION OF CASE}

A 38-year-old male working as a mechanic had decreased perception of sensation in both upper limbs and lower limbs since 1 year. He had tingling with pins and needles sensation and had a feel of walking on cotton wool. He had difficulty in walking, holding the slippers, standing from squatting position and inability to perform fine motor movements since 6 months. He noticed difficulty in swallowing and speech, as the tongue size was increasing for past 3 months. He had surgery for carpal tunnel syndrome in the right hand 8 months back. He is a non-smoker with no addiction and with no other comorbid illness.

On examination, his vitals were stable. He had macroglossia. His higher mental functions were normal. Cranial nerve examination was unremarkable. In motor system, bulk and tone were normal. Power was $4+/ 5$ in shoulder and elbow, 4/5 in wrist, hand grip was 50\% and in lower limb $4+/ 5$ in all joints. Both superficial and deep reflexes were preserved. Touch, pain and temperature sensation were decreased in both upper limbs upto elbow and in both lower limbs upto knee. Joint, position and vibration sense were intact. Cerebellum, extrapyramidal system and autonomic nervous system were clinically normal. Other system examination was unremarkable.

\section{DIFFERENTIAL DIAGNOSIS}

A Case of Mononeuropathy Multiplex ${ }^{1}$ which can be due to-

1. Amyloidosis.

2. Infections like HIV, HBV, HCV and Leprosy.

3. Vasculitis.

\section{CLINICAL DIAGNOSIS}

A 38-year-old male with no comorbid illness was diagnosed as a case of mononeuropathy multiplex. As the patient is having macroglossia and peripheral neuropathy as the main presentation, coming to a single clinical diagnosis is a difficult task. We proceeded with the investigations in relevance to the above said differential diagnosis.

\section{PATHOLOGICAL DISCUSSION}

Complete haemogram was normal. Renal function test, liver function test, serum electrolytes and thyroid profile were

'Financial or Other Competing Interest': None.

Submission 17-03-2018, Peer Review 04-05-2018,

Acceptance 11-05-2018, Published 21-05-2018.

Corresponding Author:

Dr. Shilpa Dharmaraj,

Flat G1, Plot 43 and 44,

VGN Krona Apartments,

Gerugambakkam, Chennai-600122,

Tamilnadu.

E-mail: shilpadhrmrj@gmail.com

DOI: $10.14260 /$ jemds $/ 2018 / 594$

\section{(c) (1) $(?$}

within normal limits. Urine examination showed 3+ proteinuria, no pus cells, urine protein creatinine ratio was 6 , 24-hour urine protein estimation was $3 \mathrm{~g} /$ day and Bence Jones protein was negative. Peripheral smear study was normal. Viral markers were negative. Serum protein electrophoresis showed normal pattern. Nerve conduction study revealed demyelinating and axonal neuropathy. Abdominal fat biopsy showed homogenous, eosinophilic amorphous material2 ${ }^{2}$, positive for congo red and had applegreen birefringence suggestive of amyloidosis.

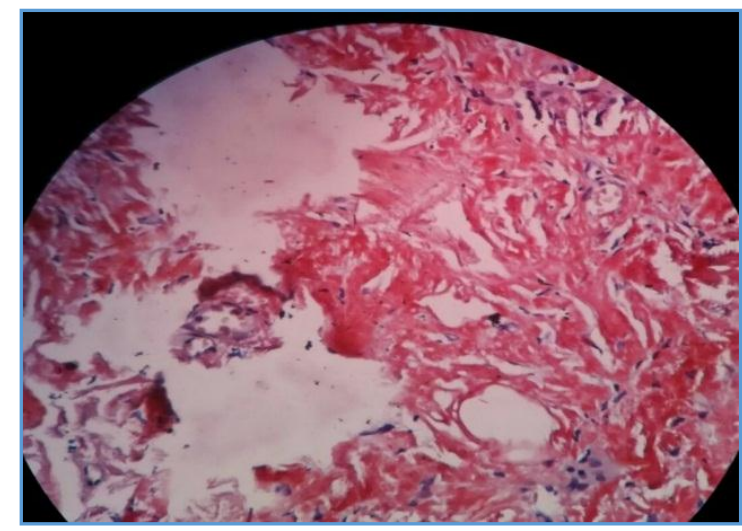

Figure 1. Homogenous Eosinophilic Amorphous Material under High Power in Light Microscope

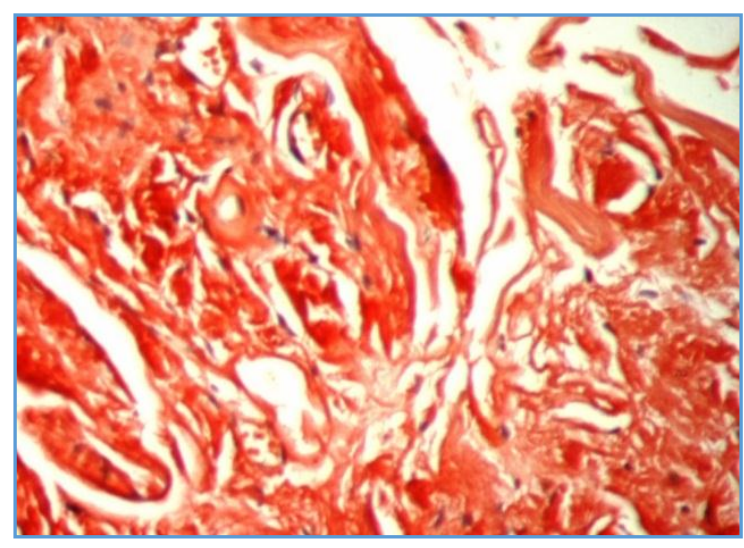

Figure 2. Congo Red Staining

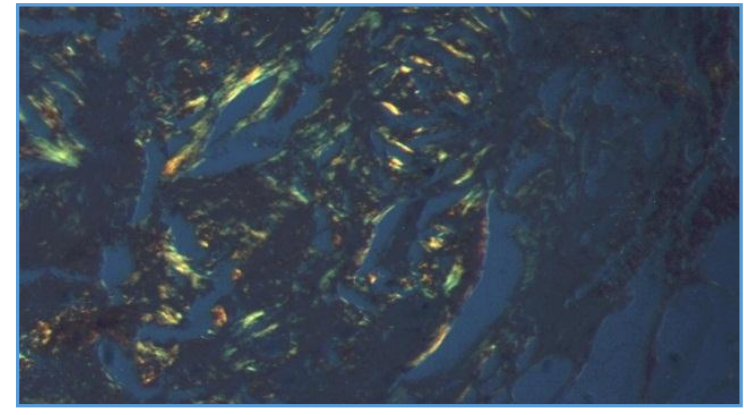

Figure 3. Apple-Green Birefringence under Polarised Light Microscope 
Nerve biopsy came out as inflammatory neuropathy favouring demyelinating neuropathy with secondary axonopathy. These investigations lead us to a definitive diagnosis of amyloidosis causing peripheral neuropathy.

We proceeded with further investigations to find out the cause for amyloidosis as given in the table below.

\begin{tabular}{|c|c|}
\hline Test & Result \\
\hline $\begin{array}{l}\text { Urine protein } \\
\text { electrophoresis }\end{array}$ & Monoclonal peak in gamma region \\
\hline $\begin{array}{c}\text { Serum free light } \\
\text { chain }(L C) \text { assay: } \\
\text { Free kappa }(\kappa) L C \\
\text { Free lambda }(\lambda) \mathrm{LC} \\
\kappa / \lambda \text { ratio } \\
\end{array}$ & $\begin{array}{c}43.68 \mathrm{mg} / \mathrm{L}(3.3-19.4) \\
30.74 \mathrm{mg} / \mathrm{L}(5.7-26.3) \\
1.42(0.26-1.65)\end{array}$ \\
\hline $\begin{array}{c}\text { Serum } \\
\text { immunofixation } \\
\text { electrophoresis }\end{array}$ & $\begin{array}{l}\text { Free kappa light chain deposition } \\
\text { disease }\end{array}$ \\
\hline $\begin{array}{c}\text { Urine } \\
\text { immunofixation } \\
\text { electrophoresis }\end{array}$ & Free $\kappa, \lambda$ light chains \\
\hline Bone marrow study & $\begin{array}{c}\text { Moderately cellular marrow with normal } \\
\text { appearing erythroid and myeloid } \\
\text { precursors. Occasional plasmacytoid } \\
\text { cells and amorphous eosinophilic } \\
\text { material was also seen. Plasma cells } \\
\text { were CD-138 positive. } \lambda \text { negative and } \kappa \\
\text { positive. }\end{array}$ \\
\hline
\end{tabular}

Plain x-rays of chest, skull, spine showed no abnormality. CECT chest and abdomen had lytic lesions in D6, D8, L3 and L5 vertebral bodies. MRI spine revealed collapse of D6 vertebra.

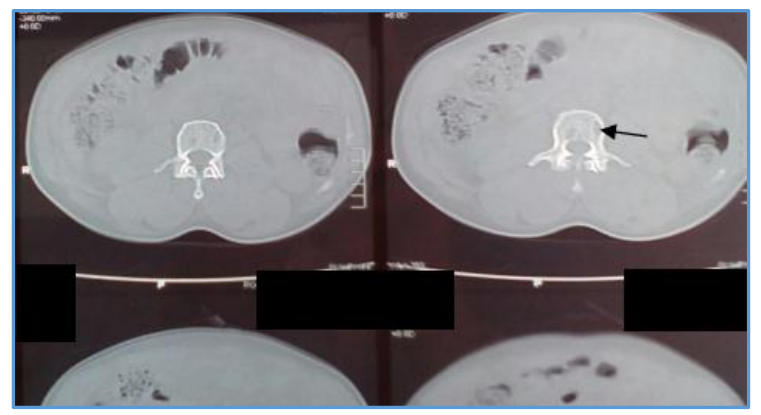

Figure 4. CECT Abdomen showing Lytic Lesions in the Vertebral Body

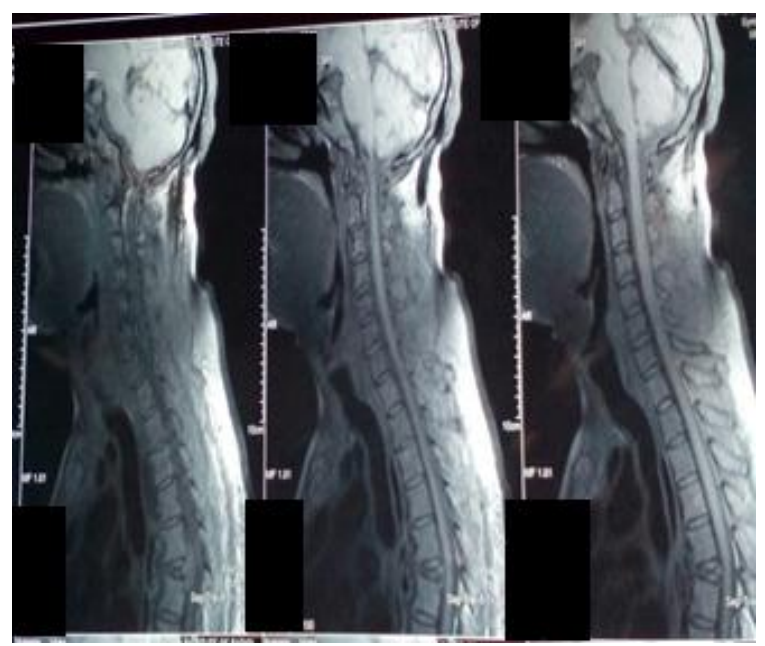

Figure 5. MRI Spine showing Collapse of D6 Vertebra

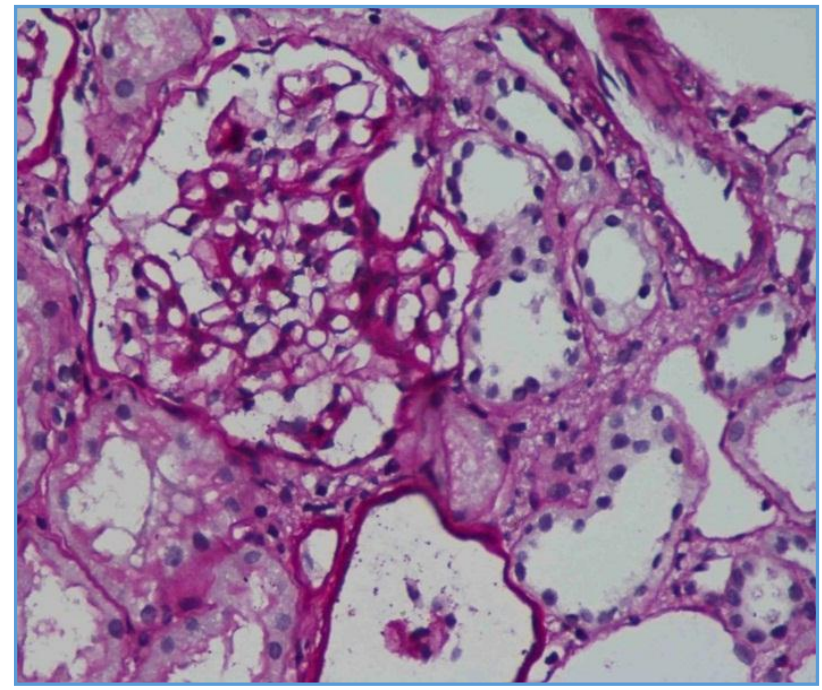

Figure 6. Renal Biopsy showing Amyloid Deposits

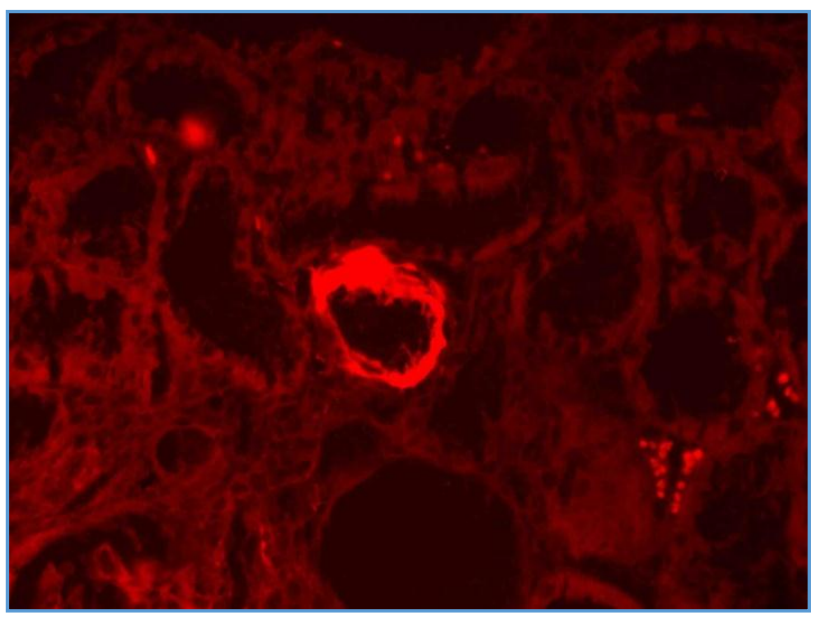

Figure 7. Renal Biopsy showing Congo Red Positive Deposits

In Echocardiogram, concentric left ventricular hypertrophy with grade I diastolic dysfunction was noticed. Troponin T levels were normal. Renal biopsy had very focal amyloid deposits. In this patient though he had lytic lesions in vertebrae, bone marrow study and immunofixation studies were not confirmative of multiple myeloma. Amyloidosis itself can form lytic lesions. ${ }^{3}$

Many diseases are now postulated to arise from the failure of proteins to adopt functional conformational states. ${ }^{4}$ Amyloidosis is one such entity broadly classified into systemic or localised; inherited or acquired. The standard nomenclature is $\mathrm{AX}$, where $\mathrm{A}$ represents amyloidosis, $\mathrm{X}$ represents the protein present in the fibril.

$\mathrm{AL}$ amyloidosis can be due to clonal plasma cells that produce light chains or over expansion from multiple myeloma or other B lymphoproliferative diseases. Myeloma patients have high plasma cell burden present with features of hypercalcaemia, renal failure, anaemia and lytic bone lesions. Amyloidosis patients have small plasma cell clone with features involving one or more organ. AL amyloidosis classically presents with syndromes. The most common among them is renal involvement with nephrotic-range proteinuria or renal failure followed by cardiomyopathy with thick walled heart, low voltage ECG, pericardial and pleural 
effusion. ${ }^{4}$ Cholestatic hepatopathy, peripheral neuropathy, autonomic neuropathy, infiltration of soft tissues like macroglossia and purpura including periorbital ecchymoses ${ }^{4}$ are other less common presentations.

\section{DISCUSSION OF MANAGEMENT}

Whenever a patient is suspected of amyloidosis, tissue biopsy or biopsy of the involved organ is done. Typing of protein deposits is performed by means of immunohistochemistry, flow cytometry or in situ hybridisation for LC mRNA. ${ }^{4}$ Later investigations are based on the organ involved and to identify any chronic inflammatory states. So our patient is a case of acquired systemic amyloidosis with kappa light chain deposition (AL amyloidosis) involving peripheral nerves, kidney, heart, vertebrae and tongue.

Treatment of amyloidosis targets clonal plasma cells, similar to the approach for multiple myeloma. 5 Oral melphalan, prednisolone and dexamethasone are in use but rarely lead to remission. Immunomodulators like thalidomide, lenalidomide and pomalidomide are being used now. The proteasome inhibitor bortezomib 5 is found to be effective. Intravenous melphalan followed by autologous stem cell transplantation results in complete haematological responses in almost $40 \%$ of treated patients.

Our patient was treated with dexamethasone, bortezomib and lenalidomide combinations monthly with other supportive measures. $\mathrm{He}$ is on regular follow-up and improving. After 6 cycles of this therapy proteinuria, free light chain assay and serum/urine immunofixation electrophoresis were normal and showed a complete response to treatment. ${ }^{6} \mathrm{He}$ is on regular follow-up for the past 2 years and he is continuing his regular job.

Median survival period without treatment is 1 to 2 years from diagnosis. Now with the availability of advanced diagnostic modalities, early intervention with newer chemotherapeutic agents will prolong the survival period. Moreover, a multimodality approach will improve the quality of life among amyloid sufferers and hence decrease the disease burden.

\section{FINAL DIAGNOSIS}

Our patient is a case of acquired systemic amyloidosis with kappa light chain deposition (AL amyloidosis) involving peripheral nerves, kidney, heart, vertebrae and tongue.

\section{REFERENCES}

[1] Ropper AH, Samuels MA, Klein J. Adam and Victor's principles of neurology. 10 $0^{\text {th }}$ edn. McGraw-Hill Education, 2014.

[2] Kumar V, Abbas A, Aster J. Robbin's basic pathology. $9^{\text {th }}$ edn. Elsevier, 2012;Vol 1.

[3] Schonland SO, Hansmann J, Mechtersheimer G, et al. Bone involvement in patients with systemic $\mathrm{AL}$ amyloidosis mimics lytic myeloma bone disease. Haematologica 2008;93(6):955-6.

[4] Merlini G, Seldin DC, Gertz MA. Amyloidosis: pathogenesis and new therapeutic options. J Clin Oncol 2011;29(14):1924-33.

[5] Jameson JL, Kasper D, Hauser S, et al. Harrison's principles of internal medicine. 19th edn. McGraw Hill Education, 2015; Vol 2.

[6] Gertz MA, Comenzo R, Falk RH, et al. Definition of organ involvement and treatment response in immunoglobulin light chain amyloidosis (AL): a consensus opinion from the $10^{\text {th }}$ international symposium on amyloid and amyloidosis. Am J Hematol 2005;79(4):319-28. 